\title{
ANALISIS ISLAMIC BRANDING TERHADAP KEPUTUSAN PEMBELIAN KOSMETIK WARDAH MELALUI BRAND AWARENESS SEBAGAI MEDIASI PADA REMAJA WANITA DI KOTA MAKASSAR
}

\author{
Nurul Aisyah 1, Muh. Akil Rahman ${ }^{2}$, Sitti Aisyah ${ }^{3}$ \\ 1,2,3, Universitas Islam Negeri Alauddin Makassar \\ Email: na5732887@gmail.com¹, muhakil.rahman@uin-alauddin.ac.id², \\ icaiwan68@gmail.com ${ }^{3}$
}

\begin{abstract}
Abstrak:
Penelitian ini bertujuan untuk: 1) Menganalisis pengaruh Islamic branding terhadap keputusan pembelian; 2) Menganalisis pengaruh Islamic branding terhadap brand awareness; 3) Menganalisis pengaruh brand awareness terhadap keputusan pembelian; dan 4) Menganalisis pengaruh Islamic branding terhadap keputusan pembelian melalui brand awareness sebagai variabel intervening. Penelitian ini merupakan jenis penelitian asosiatif dengan pendekatan kuantitatif. Populasi dalam penelitian ini adalah remaja wanita pengguna kosmetik Wardah di Kota Makassar. Teknik pengambilan sampel yang digunakan yaitu simple random sampling. Jumlah sampel sebanyak 100 responden dengan menggunakan rumus Slovin. Data yang digunakan merupakan data primer yang berasal dari jawaban kuesioner dengan menggunakan skala pengukuran semantic differential. Pengolahan data primer menggunakan analisis statistical package for social science (SPSS 23) dengan menggunakan metode koefisien determinasi $\left(\mathrm{R}^{2}\right)$, uji-t, dan analisis jalur (path analysis). Hasil penelitian menunjukan bahwa 1) Islamic branding berpengaruh positif dan tidak signifikan terhadap keputusan pembelian; 2) Islamic branding berpengaruh positif dan signifikan terhadap brand awareness; 3) Brand awareness berpengaruh positif dan signifikan terhadap keputusan pembelian; dan 4) Islamic branding berpengaruh positif dan signifikan terhadap keputusan pembelian melalui brand awareness.
\end{abstract}

Kata Kunci: Branding Islam, Keputusan Pembelian, Kesadaran Merek

\section{ABSTRACT:}

This research were aimed to: 1) analyze the influence of Islamic branding on purchasing decisions; 2) analyze the influence of Islamic branding on brand awareness; 3 ) examine the influence of brand awareness on purchasing decisions; and 4) outline the influence of Islamic branding on purchasing decisions through brand awareness as an intervening variable. This research was an associative research type with a quantitative approach. The population in this study were young women using Wardah cosmetics in Makassar City. The sampling technique used was simple random sampling. The number of samples were 100 respondents using the Slovin formula. The data used were primary data derived from questionnaire answers using a semantic differential measurement scale. Primary data processing used statistical package for social science (SPSS 23) analysis using the coefficient of determination (R2), t-test, and path analysis methods. The results showed that 1) Islamic branding had a positive and insignificant effect on purchasing decisions; 2) Islamic branding had a positive and significant effect on brand awareness; 3) Brand awareness had a positive and significant effect on purchasing decisions; and 4) Islamic 
branding had a positive and significant effect on purchasing decisions through brand awareness.

Keywords: Buying Decision, Brand Awareness, Islamic Branding

\section{PENDAHULUAN}

Penduduk muslim terbesar di dunia salah satunya berada di Indonesia. Berdasarkan data yang dilansir dari salah satu website, tahun 2016 sebanyak 222 juta penduduk muslim di Indonesia atau sekitar $87 \%$ dari total populasi. Pencapaian Indonesia sebagai negara muslim terbesar tahun 2016 diproyeksikan meningkat di tahun 2020 mencapai 229,62 juta jiwa. Dengan jumlah penduduk yang besar memberikan pengaruh yang banyak terhadap perkembangan bisnis dan sekaligus menempatkan Indonesia sebagai pasar potensial untuk segala produk dan jasa termasuk usaha produk kosmetik. (www.marketing.co.id, 2004). Di kalangan produsen muncul kesadaran jika pendudukan muslin sasaran yang efektif dalam memasarkan produk. Hal ini terlihat dari pertumbuhan industri kosmetik pada tahun 2018 sekitar 7,3\% meningkat 9\% di tahun 2019 berdasarkan data Kementerian Perindustrian (www.kemenperin.go.id).

Dalam melihat kebutuhan dan keinginan masyarakat atau konsumen maka produsen dituntut untuk dapat memahami kecenderungan konsumen. Di kalangan konsumen yang mayoritas muslim, penggunaan identitas Islam misalnya labelisasi halal atau symbol nama-nama yang islami, syariah menjadi salah satu pilihan strategi yang dapat diimplementasikan para produsen. Upaya ini erat kaitannya dengan strategi dari produsen untuk membangun atau memperkenalkan identitas islamic branding pada produk yang ditawarkan kepada konsumen. Terkait dengan penamaan islamic branding oleh Alsheran, 2010 mengklasifikasinya dalam tiga bagian yaitu, Islamic branding by origin, by customer, and by compliance

Maraknya fenomena hijrah di tengah kaum millennial menyebabkan semakin banyak yang memilih produk kosmetik bersertifikasi halal. Hakikat hijrah merupakan perubahan kualitas diri kearah yang lebih baik secara Islam dilakukan oleh individu maupun kelompok tanpa meninggalkan ketentuan syariat secara 
batiniah dan lahiriah serta menjauhkan diri dari segala larangan Allah secara konsisten (Aswadi, 2011). Dalam pengimplikasiannya para pengusaha melakukan terobosan guna memasarkan produk mereka dengan menggunakan branding Islami yang dimaksud dalam hal ini yaitu pemberian label halal pada produk. Kehalalan suatu produk menjadi parameter utama yang perlu dipertimbangkan termasuk kosmetik. Memanfaatkan produk halal merupakan sebuah kewajiban bagi umat muslim karena apapun yang dikonsumsi akan mendarah daging dalam tubuh manusia.

Branding di kalangan umat Muslin, merupakan sesuatu yang menyatu dengan iman, dalam artian bahwa seluruh aktifitas seorang Muslim bersandar pada nilai-nilai ilahia. Seseorang mencintai dan membenci tidak berdasar keinginan individu atau manusiawi namun perasaannya disebabkan sejalan dengan tuntunan Allah (Yulfan, 2017). Islam memberi instruksi terperinci mengenai apa itu diizinkan dan apa yang tidak diizinkan tentu merujuk pada pedoman umat muslim dalam alquran dan hadis. Kunci dasar keunikan yang membuat Islamic branding berbeda di mana produsen tidak memproduksi barang, mereka memproduksi kebenaran, penjual tidak memperdagangkan benda, mereka mengajak pada kehidupan yang benar, pembeli tidak membeli kebutuhan serta kenyamanan materi melainkan mereka terlibat dalam ibadah.

Menghadapi kondisi di atas muncullah berbagai perusahaan yang berorientasi pada prioritas kehalalan produk salah satunya PT. Paragon Technology and Innovation bergerak di bidang produksi kosmetik, perusahaan ini didirikan tahun 1985 dan telah mendapat sertifikat GMP (Good Manufacturing Practice). Wardah cosmetics merupakan salah satu brand dari PT. Paragon Technology and Innovation sebagai pionir brand halal di Indonesia. Pada tahun 1999 produk wardah cosmetics mendapat sertifikat halal MUI yang memberikan jaminan kebaikan produk serta bahan baku produksi kosmetik halal sesuai dengan syariat Islam. Perusahaan kosmetik yang didirikan sejak 1995 tersebut menjadi contoh bagaimana suksesnya produsen kosmetik di pasar muslim (Salaka EP, 2019). Pengertian brand awareness sendiri dapat kita merujuk pada pendapat Aaker, 1991, dimana dikemukakan bahwa brand awareness merupakan sebuah 
kemampuan seseorang pembeli potensial dalam mengenali atau mengingat bahwa sebuah merk adalah bagian dari sebuah kategori produk tertentu. Brand awareness dalam kaitannya dengan benak konsumen dalam hal pembentukan nilai terdiri atas susunan yaitu, merek tersebut tidak disadari (brand unware), merek dikenali (brand recognition), ada proses merek itu diingat kembali (brand recall), serta pada bagian tertinggi ialah puncak pikiran (top of mind) dimana ketika seorang konsuen ditanyakan tentang kategori sebauh produk dipasaran maka suatu merek pertama kali muncul dalam benak konsumen.

Pada aspek lain, dalam hal pengambilan keputusan oleh konsumen maka diyakini salah satu instrument yang berpengaruh terhadap konsumen adalah brand awareness. Kondisi tersebut tidak terlepas dari sifat dasar sebagian konsumen yang senantiasa mencari dan membutuhkan produk yang aman dan telah teruji. Hal ini tercermin dari perilaku konsumen pada umumnya cenderung untuk memutuskan untuk membeli sebuah produk dimana brand dari produk tersebut sudah terkenal dibanding produk dengan brand yang kurang terkenal bahkan tidak dikenal sama sekali. pernyataan ini sesuai juga dengan hasil penelitian oleh Choirunisa (2018) dimana hasil penelitiannya menunjukkan variable kesadaran merek berpengaruh signifikan terhadap keputusan pembelian.

Kondisi ini terjadi dengan adanya ketersediaan informasi yang mendukung dan dapat menjadikan seorang konsumen mengambil keputusan pembelian.

Kecenderungan konsumen dalam pengambilan keputusan pembelian berhubungan dengan tindakan pembelian pada saat tertentu dimana objek barang maupun atribut barang memiliki peran penting. Konsumen pada umumnya akan mengawali tindakan ini dengan mencari informasi akan sebuah produk atau jasa yang akan dibeli. Terkait pembelian produk kosmetik wardah, berbagai macam faktor dapat memengaruhi keputusan pembelian konsumen. Oleh karena setiap kosmetik memiliki keunggulan berbeda baik dari segi harga, bahan baku, kualitas produk, labeling halal terutama di Indonesia masyarakatnya mayoritas muslim sangat disarankan bagi calon konsumen yang akan membeli serta menggunakan produk diwajibkan mencari tahu terlebih dahulu informasi produk yang akan digunakan. 
Brand Wardah merupakan kosmetik yang secara maksimal menampakan citra sebagai perusahaan yang terus berkomitmen menghasilkan produk halal berkualitas dengan terus melakukan inovasi di bidang Research and Innovation mulai dari bahan baku, proses pembuatan sampai pengemasan. Dengan mengusung tagline "Halal dari Awal", ini menunjukkan bahwa Wardah berkomitmen terhadap kesadaran penggunaan produk halal dan mengembangkan industri kecantikan dalam negeri dengan label halal dapat terus meningkatkan pemahaman konsumen. Hal tersebut menunjukkan bagian dari Islamic branding sehingga terciptalah brand awareness (kesadaran merek) yang tentunya mampu memengaruhi keputusan pembelian brand kosmetik Wardah.

Kalangan remaja wanita merupakan salah satu kelompok sosial dalam masyarakat yang dianggap rentan terpengaruh gaya hidup. Kosmetik adalah bagian gaya hidup dari para remaja, seringkali mereka mengikuti tren gaya make-up dan jenis produk kosmetik yang sedang populer untuk memperoleh penampilan sempurna. Berbagai varian kosmetik yang ditawarkan oleh wardah bagi semua kalangan baik kaula muda sampai yang sudah berumur mulai dari bodyseries, skincare, make-up sehingga menimbulkan pandangan masyarakat Indonesia khususnya kaum remaja wanita dengan mudah dapat terpengaruh untuk membeli serta memanfaatkan produk wardah karena menawarkan berbagai macam produk untuk berbagai macam jenis kulit dan produknya mudah diperoleh di berbagai tempat.Berdasarkan uraian latar belakang di atas, maka menjadi hal yang menarik untuk dianalisis apakah Islamic branding berpengaruh terhadap keputusan pembelian kosmetik Wardah yang dimediasi brand awareness pada remaja wanita di Kota Makassar".

\section{TINJAUAN PUSTAKA}

\section{Perilaku Konsumen}

Secara teori, definisi perilaku konsumen dapat dirujuk pada beberapa pendapat para ahli. Menurut Dharmmnesta dan Handoko (2000) perilaku konsumen adalah individu yang terlibat dalam kegiatan secara langsung guna memeroleh dan memakai barang serta jasa dimana dalam prosesnya termasuk 
pengambilan keputusan untuk mempersiapkan dan menentukan aktifitas tertentu. Ada juga pendapat yang menyatakan bahwa perilaku konsumen merupakan gambaran dari upaya seseorang mengambil keputusan dalam menggunakan sumber daya yang dimiliki agar dapat memenuhi kebutuhan barang konsumsi (Schiffman dan Kanuk, 2008).

Dari dua pengertian di atas maka secara singkat perilaku konsumen dapat disimpulkan sebagai kesleuruhan aktifitas, tindakan dan proses psikologis pada diri seorang konsumen baik sebelum pembelian barang dan jasa, saat pembelian, kemudian saat digunakan, dihabiskan dan terakhir melakukan evaluasi. Kajian perilaku konsumen merupakan sesuatu yang kompleks oleh sebab adanya faktorfaktor yang berpengaruh serta cenderung saling berkaitan pada aspek aktifitas fisik maupun dalam langkah-langkah seorang konsumen mengambil keputusan.

\section{Islamic Branding}

Istilah Islamic branding mengacu pada merek dengan berdasar pada nilainilai syariah yang ditandai dengan adanya prinsip-prinsip kejujuran, repek pada akuntabulitas serta pemahaman inti terhadap ajaran-ajaran pokok syariah. Seperti yang dikemukakan oleh Oglivynoor dalam artikelnya "what is Islamic branding an why is it significant?" dan dijelaskan jika Islamic branding masih merupakan konsep yang tergolong baru (Ranto, 2013). Islamic branding memiliki tujuan bagaimana konsumen khususnya dari muslim memiliki ketertarikan terhadap barang dan jasa baik dari segi perilaku maupun komunikasi pemasaran yang dilakukan. Hal ini diterapkan melalui penerapan empati dengan nilai-nilai syariah.

Saat ini konsumen sudah tidak asing lagi dengan istilah Islamic branding dikarenakan istilah ini dengan mudah ditemui dimana saja. Hal ini tidak terlepas dari strategi perusahaan produk maupun jasa dalam mensegmentasi konsumen. Pihak perusahaan menyadari bahwa muslim Indonesia merupakan pangsa pasar yang besar (Ranto,2013).

\section{Brand Awareness}


Brand Awarness atau kesadaran merek merupakan kondisi calon konsumen yang memiliki kemampuan dalam mengenal suatu merek dan mengingatnya kembali dimana merek ini salah satu bagian dari kategori pada sebuah produk. Hal ini perlu mendapatkan perhatian disebabkan hubungan antara kategori produk dengan keterlibatan merek terjalin begitu kuat. Pada diri konsumen perlu dibangun keyakinan akan perasaan yang pasti bahwa dalam sebuah kelompok produk, merek yang selama ini dikenal menjadi satu-satunya merek. Oleh karena itu maka jangkauan kontinum dari perasaan konsumen sangat dibutuhkan dalam membangun kesadaran merek. produk yang selama ini dikenal menjadi satusatunya

Dalam menyusun ekuitas merek, maka komponen yang terpenting adalah kesadaran merek. Fenomena umum bahwa sepanjang merek tersebut yang sudah dikenal oleh konsumen dapat memberikan kenyamanan, keamanan, dan sebagainya maka kecenderungan konsumen untuk memilih produk tersebut akan sangat besar. Kondisi ini berangkat dari naluri konsumen untuk tidak mau menanggung resiko atas penggunaan produk atau jasa yang telah dibeli. Dalam benak konsumen, merek yang terkenal tentunya dapat diandalkan sehingga peran merek bagi perusahaan perlu diperluas melalui mekanisme peningkatan kesadaran merek di kalangan konsumen. Konsumen yang meningkat kesadarannya akan sebuah merek dapat memengaruhi perilaku dan persepsinya. Oleh karena itu kesadaran merek menjadi kunci pembuka bagi sebuah produk maupun jasa untuk memperkenalkan bagian-bagian lain. Sebuah produk atau jasa yang memiliki kesadaran merek di kalangan konsumen bisa dipastikan juga memiliki ekuitas merek yang rendah.

\section{Keputusan Pembelian}

Keputusan pembelian menurut Kotler dan Amstrong (2011) merupakan bagian dari tahapan seorang pembeli mengambil keputusan setelah melakukan penelitian. Mowen dan Minor (2008) mengemukakan bahwa konsumen dalam mengambil keputusan ada proses yang dilaluia dimana proses itu meliputi keseluruhan bagian dimana konsumen melaluinya untuk dapat mengindentifikasi 
masalah, kemudian menemukan solusi, lalu mengevaluasi berbagai macam pilihan dan kemudian memilih satu dari pilihan-pilihan tersebut. Ada juga pendapat dari Tjiptono (2008) terkait dengan keputusan pembelian yang menyatakan bahwa memilih satu tindakan dari dua atau lebih pilihan merupakan keputusan pembelian. Berdasarkan pengertian yang dikemukakan oleh beberapa ahli di atas tentang keputusan pembelian yang dibutuhkan dan diinginkan maka dapat disimpulkan jika keputusan pembelian merupakan cara konsumen membeli produk atau jasa yang diawali dari proses mencari, kemudian memilih dan dilanjutkan dengan mengambil keputusan pembelian dari berbagai macam pilihan produk dengan kriteria yang telah ditentukan.

\section{Kerangka Konseptual dan Hipotesis Penelitian}

Dalam penelitian ini, sesuai dengan kajian teoritis dan penelitian yang telah dilakukan sebelumnya, maka model kerangka konseptual pada penelitian ini menjelaskan bahwa Islamic branding berpengaruh terhadap keputusan pembelian, baik secara langsung maupun tidak secara langsung atau melalui Brand awareness sebagai variable intervening,. Lebih lengkap dapat dilihat pada Gambar 1 di bawah:

Gambar 1

Kerangka Konseptual

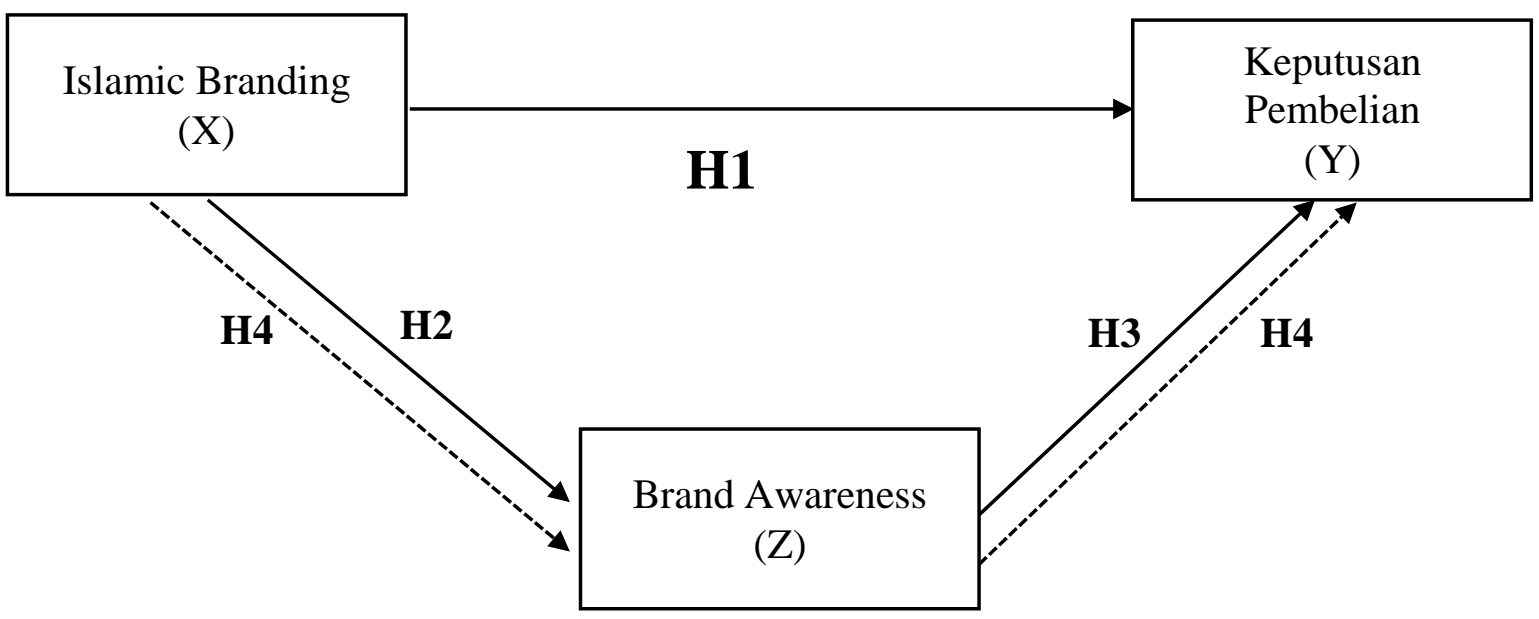

Kerangka konseptual di atas menjelaskan bentuk hubungan ketiga jenis variabel dalam penelitian ini. Islamic branding diduga berpengaruh terhadap keputusan pembelian konsumen karena umat muslim tidak sekedar memproduksi, 
menggunakan produk melainkan perlu memperhatikan sisi kehalalan, kesucian, dan kesehatan suatu produk karena hukumnya wajib dalam perintah agama Islam. Brand Awareness dapat timbul sebagai alasan terjadinya keputusan pembelian karena ditinjau dari pemanfaatan konsep Islamic branding yang diusung oleh produsen sehingga konsumen dapat lebih mudah mengingat, mengenali suatu brand. Akan lebih berpotensi konsumen memilih brand tersebut ketika suatu brand telah melekat di benak para konsumen.

Hipotesis merupakan dugaan sementara terhadap masalah yang masih bersifat praduga karena masih perlu dibuktikan kebenarannyaMengacu pada pemaparan penelitian terdahulu, maka dapat dijabarkan hipotesis penelitian sebagai berikut:

H1 : Diduga Islamic branding berpengaruh positif terhadap keputusan pembelian.

H2 : Diduga Islamic branding berpengaruh positif terhadap Brand awareness.

H3 : Diduga Brand awareness berpengaruh positif terhadap keputusan pembelian. H4 : Diduga Islamic branding berpengaruh positif terhadap keputusan pembelian melalui Brand awareness sebagai variable intervening.

\section{METODE PENELITIAN}

Jenis penelitian yang digunakan adalah asosiatif atau hubungan. Jenis penelitian asosiatif digunakan penulis untuk mengetahui dan menguji ada tidaknya pengaruh antara Islamic branding terhadap keputusan pembelian melalui brand awareness. Lokasi penelitian dilakukan di Sulawesi Selatan tepatnya di Kota Makassar. Pendekatan dalam penelitian ini menggunakan pendekatan kuantitatif. Populasi penelitian dalam kategori rentang usia remaja wanita 17-24 tahun di Kota Makassar berjumlah 180.078 jiwa. Penentuan sampel menggunakan teknik simple random sampling. Terdapat beberapa kriteria sampel dalam penelitian ini, yaitu remaja wanita berusia 17-24 tahun, telah dan masih menggunakan produk Wardah minimal 3 bulan, serta berdomisili di Kota Makassar. Dalam penelitian ini menggunakan kuesioner, studi pustaka, dan observasi dalam metode pengumpulan data. Sumber data berasal dari data primer dan data sekunder, dengan skala 
pengukuran menggunakan skala semantic differential yang memiliki rentang 1 sampai 7.

Dalam penelitian ini dilakukan uji validitas dan reliabilitas. Sementara untuk pengolahan dan analisis data dilakukan dengan menggunakan analisis statistik. Adapun teknik yang dipergunakan oleh peneliti, yaitu : 1) uji asumsi klasik meliputi empat pengujian yang harus terpenuhi diantaranya uji multikolinearitas, uji autokorelasi, uji heteroskedastisitas, dan uji normalitas. 2) metode pengujian hipotesis diukur dengan melihat uji analisis regresi sederhana, koefisien determinasi, nilai statistik t, dan nilai statitik f. 3) Analisis jalur (path analysis).

\section{HASIL DAN PEMBAHASAN}

Berikut ini merupakan pembahasan dari hasil analisis yang telah dilakukan, dengan tujuan agar dapat memberikan gambaran yang lebih jelas dan mendetail pada pengaruh yang terjadi antar variabel dalam penelitian ini. Adapun pembahasan dari setiap hubungan antar variabel akan dijelaskan sebagai berikut:

\section{Pengaruh Islamic Branding Terhadap Keputusan Pembelian}

Hasil dari analisis membuktikan bahwa Islamic branding berpengaruh positif dan tidak signifikan terhadap keputusan pembelian, hal ini dibuktikan dari nilai koefisien regresi sebesar 0,116 bernilai positif (+) yang memberi makna bahwa variabel Islamic branding memiliki pengaruh positif terhadap keputusan pembelian. Variabel Islamic branding juga menghasilkan nilai t-hitung sebesar 1,141 lebih kecil dari t-tabel yang bernilai 1,985 serta nilai signifikansi sebesar 0,257 atau lebih besar dari 0,05. Nilai yang dihasilkan tersebut tidak menunjukan ketentuan atas diterimanya sebuah hipotesis, oleh karena itu variabel Islamic branding tidak berpengaruh signifikan terhadap keputusan pembelian.

Hasil analisis dari variabel Islamic branding berpengaruh terhadap keputusan pembelian dalam penelitian ini sesuai dengan hasil penelitian oleh Ozgen (2013) dimana dinyatakan jika islamic branding tidak memiliki pengaruh yang signifikan terhadap keputusan pembelian. Dijelaskan pula bahwa Islamic branding ada atau tidak ada pada produk merek Coklat, bagi konsumen bukan 
pertimbangan dalam mengambil keputusan pembelian. Pembeli atau konsumen akan lebih memilih persoalan rasanya, harga, atau faktor lain yang belum diteliti

Konsep Islamic branding yang diterapkan oleh Wardah kosmetik belum bisa menjadikan prioritas bagi konsumen dalam memutuskan pembelian. Alasan yang pertama tidak keseluruhan konsumen Wardah adalah muslim, non-muslim pun mulai menjadikan kosmetik Wardah sebagai pilihan mereka karena Wardah memiliki beragam variasi produk, berkualitas tinggi, pas diaplikasikan untuk semua jenis kulit diluar dari segi kehalalan sebagaimana yang dijadikan patokan oleh umat muslim. Alasan berikutnya beranjak dari opini sebagian kalangan muslim yang menyatakan jika tidak ada informasi keharaman sebuah produk dari lembaga yang berwenang maka produk tersebut dapat diyakini kehalalannya, sehingga pemberian label halal pada sebuah produk tidak perlu. Informasi yang dibutuhkan adalah apakah produk tersebut memiliki zat yang diharamkan, apakah produk tersebut bercampur dengan barang haram atau mengalami kontaminasi dengan barang haram lainnya.

Kondisi tersebut membentuk pola fikir sebahagian masyarakat untuk tidak begitu mengedepankan labelisasi yang tercantum pada produk. Terlebih diketahui Indonesia merupakan negara dengan populasi umat muslim terbesar di dunia, konsumen mudah saja beranggapan bahwa produk yang dipasarkan dalam negeri secara keseluruhan telah terjamin kualitas dan mutu berdasarkan ketentuan agama karena ditujukan bagi konsumen muslim sehingga membuat produk manapun bisa saja populer karena faktor harga yang lebih murah dan beberapa faktor lain dengan demikian produk berkonsep Islamic mudah saja terkalahkan oleh produk lain. Berbeda halnya ketika produk Islamic branding dipasarkan ke negara minoritas muslim pastinya produk tersebut akan menjadi incaran kaum muslim karena mereka lebih mengutamakan labelisasi halal sebagai langkah selektif untuk menghindari penggunaan produk terlarang yang banyak mendominasi di negara tersebut.

\section{Pengaruh Islamic Branding Terhadap Brand Awareness}


Hasil dari pengujian membuktikan bahwa Islamic branding terhadap brand awareness berpengaruh positif dan signifikan, hasil tersebut dibuktikan dengan nilai koefisien regresi sebesar 0,406 bernilai positif (+) yang artinya variabel Islamic branding memiliki pengaruh positif terhadap brand awareness. Variabel Islamic branding juga mempunyai nilai t-hitung sebesar 6,495 atau lebih besar dari nilai t-tabel senilai 1,984 serta nilai signifikansi sebesar 0,000 yang menunjukan nilai tersebut lebih kecil dari 0,05 sehingga menjadikan variabel Islamic branding berpengaruh signifikan terhadap brand awareness.

Adapun hasil penelitian yang mendukung dilakukan oleh Raufu, dan Bakar (2014), serta Girard, et al (2013) menyatakan bahwa produsen memutuskan untuk memasang logo halal guna memberikan informasi dan meyakinkan konsumen bahwa produknya halal serta sesuai syariat agama Islam. Ketertarikan mengenai logo halal sebagai salah satu bagian dari konsep Islamic branding tersebut berpengaruh terhadap brand awareness suatu produk, dimana mayoritas konsumen Indonesia mengaku mampu mengenali logo halal terlebih ketika suatu produk jelas adanya menunjukan ciri khas konsep brand Islam tidak hanya sebatas logo halal saja.

\section{Pengaruh Brand Awareness Terhadap Keputusan Pembelian}

Berdasarkan hasil analisis dan berbagai pengujian yang telah dilakukan, membuktian bahwa brand awareness terhadap keputusan pembelian berpengaruh positif dan signifikan, hal ini ditunjukan dari perolehan nilai koefisien regresi sebesar 0,790 bernilai positif (+) artinya variabel brand awareness mempunyai pengaruh yang positif terhadap keputusan pembelian. Untuk nilai t-hitung menghasilkan perolehan sebesar 5,764 atau lebih besar dari nilai t-tabel yaitu 1,985 sedangkan nilai signifikansi sebesar 0,000 atau lebih kecil dari 0,05 sehingga variabel brand awareness berpengaruh signifikan terhadap keputusan pembelian. Hasil penelitian ini sejalan dengan penelitian yang dilakukan oleh Siahaan (2016), dengan judul "Pengaruh tingkat brand awareness terhadap keputusan pembelian produk Victoria Secret" (Studi pada konsumen Victoria Secret di PVJ Bandung) berdasarkan hasil pengujian kedua variabel membuktikan bahwa brand awareness 
berpengaruh positif dan signifikan terhadap keputusan pembelian. Teori dari Aaker (1997) juga mendukung hasil dari penelitian ini, bahwa kesadaran merek merupakan kesanggupan seorang individu dalam hal ini pembeli untuk mengingat atau mengenali kembali bahwa suatu brand adalah salah satu bagian dari kategori produk tertentu.

\section{Pengaruh Islamic Branding Terhadap Keputusan Pembelian Melalui}

\section{Brand Awareness}

Dari hasil pengujian analisis jalur (path analysis) diperoleh hasil bahwa brand awareness mampu menjadi mediator pengaruh Islamic branding terhadap keputusan pembelian. Hal ini dapat dilihat dari besarnya pengaruh langsung adalah 0,164836 dan pengaruh tidak langsung sebesar 0,09164 dengan total pengaruh $(0,164836+0,09164)=0,256476$. Kemudian hasil pengujian brand awareness sebagai variabel intervening dengan melihat nilai t-hitung sebesar 3,4380 yang lebih besar dari t-tabel bernilai 1,985 dengan tingkat signifikansi 0,05 sehingga dapat disimpulkan bahwa koefisien mediasi signifikan yang berarti terdapat pengaruh mediasi. Berdasarkan pada penelitian ini brand awareness mampu memediasi hubungan antara Islamic branding terhadap keputusan pembelian secara full mediation. Hasil dari penelitian ini juga relevan terhadap penelitian yang dilakukan oleh Hidayah (2019) bahwa religiusitas dan brand awareness berpengaruh secara simultan terhadap keputusan pembelian. Meski tidak melibatkan variabel intervening dari penelitian terdahulu yang dijadikan sebagai rujukan tetapi mampu memberikan gambaran dari penggunaan variabel yang serupa.

\section{KESIMPULAN}

Berdasarkan beberapa hasil pengolahan data dari hubungan antar variabel, yang pertama dinyatakan Islamic branding berpengaruh positif dan tidak signifikan terhadap keputusan pembelian. Kedua, Islamic branding berpengaruh positif dan signifikan terhadap brand awareness. Ketiga, brand awareness memiliki pengaruh 
positif dan signifikan terhadap keputusan pembelian. Keempat, Islamic branding memiliki pengaruh positif dan signifikan terhadap keputusan pembelian melalui brand awareness sebagai variabel intervening. Dari keempat hasil pengujian satu diantarannya yaitu hubungan antara Islamic branding dinyatakan tidak memiliki pengaruh signifikan terhadap keputusan pembelian oleh karena itu, kosmetik Wardah sebagai pionir brand kosmetik Islami di Indonesia harus mampu menunjukan atribut Islami sebagai dasar pembeda dengan merek lain untuk lebih meyakinkan kepada konsumen akan jaminan keamanan kualitas dari produk halal. Adapun variabel yang memiliki nilai tertinggi adalah brand awareness, produk Wardah diharapkan dapat mempertahankan identitas khusus sebagai ciri yang terbukti mampu menarik perhatian konsumen untuk membeli produk Wardah.

\section{DAFTAR PUSTAKA}

Ambar, L. (2013). Peranan Segmentasi Dalam Perilaku Konsumen Guna Menciptakan Iklan Yang Efektif". Jurnal Ekonomi Dan Kewirausahaan, 13(1).

Antika, R. W. (2019). Pengaruh Islamic Celebrity Endorser Dan Islamic Brand Image Terhadap Keputusan Pembelian Kosmetik Wardah". Febi, Ekonomi Syariah, Institut Agama Islam Negeri Purwokerto.

Badan Pusat Statistik. (2016, January 16 th). www.bps.go.id

Bambang, P. (2018). Semantic Differential Sebagai Alat Ukur Respons Estetik Siswa". Jurnal Pendidikan.

Choirunisa, Sukma, (2018). Pengaruh Citra Merek Dan Kesadaran Merek Pada Keputusan Pembelian Melalui Media Sosial Pada Kosmetik Wardah". Universitas Negeri Semarang.

Dharmmnesta, B. S., Handoko, T. H. (2000), Manajemen Pemasaran - Analisa Perilaku Konsumen, Yogyakarta : BPFE

Dirgantara, M. (2019). Pengaruh Diskon Harga Terhadap Keputusan Pembelian Pada Konsumen Matahari Department Store Mall Panakukang Dengan Minat Beli 
Sebagai Variabel Intervening di Kota Makassar". FEBI, Universitas Islam Negeri Alauddin Makassar.

Dwirahayu, G. (2013). Pengaruh Strategi Pembelajaran Eksploratif Terhadap Peningkatan Kemampuan Visualisasi Pemahaman Konsep Geometri dan Karakter Siswa". Universitas Pendidikan Indonesia.

Elfrida, Z., \& dkk. (2015). Proyeksi Penduduk Kabupaten/Kota Provinsi Sulawesi Selatan 2010-2020. Badan Pusat Statistik.

Faizah, H., \& dkk. (2018). Pengaruh Gaya Hidup dan Islamic Branding Terhadap Keputusan Pembelian Produk Wardah". Jurnal Aplikasi Bisnis, 4(2).

Fay, D. L. (1967). Dasar-Dasar Manajemen. In Angewandte Chemie International Edition, 6(11), 951-952.

Febrian, S. M. (2018). Pengaruh Brand Awareness Terhadap Keputusan Pembelian Produk Zara". Fakultas Ilmu Sosial dan Ilmu Politik, Universitas Sumatera Utara.

Fithrati, N. (2017). Pengaruh Islamic Service Quality dan Islamic Branding Terhadap Kepuasan Nasabah". Fakultas Ekonomi dan Bisnis. Universitas Islam Negeri Syarif Hidayatullah Jakarta.

Fitriya, E. (2017). Analisis Pengaruh Islamic Branding Terhadap Keputusan Konsumen Untuk Membeli Produk". Jurnal Ilmiah Akuntansi Indonesia, 2(1).

Hafiz, M. (2017). Pengaruh Islamic Branding Dan Perilaku Religious Terhadap Kepuasan Konsumen Serta Dampaknya Pada Loyalitas Konsumen Pada Produk Kosmetik Wardah". Fakultas Ekonomi dan Bisnis, Universitas Islam Negeri Syarif Hidayatullah.

Handriani, N. (2021). Pengaruh Inovasi Produk, Label Halal, dan Brand Image Produk Wardah Terhadap Loyalitas Konsumen Muslimah di Kota Jambi". Fakutas Ekonomi dan Bisnis Islam. Universitas Islam Negeri Sulthan Thaha Saifuddin.

Industri Kosmetik Nasional Tumbuh 20\%. (2018, March 20 $\left.0^{\text {th }}\right)$. www.kemenperin.go.id. 
Irawan, A. (2019). Pengaruh Viral Marketing dan Endorser Terhadap Keputusan Pembelian Dengan Brand Awareness Sebagai Variabel Intervening”. Febi, Universitas Islam Negeri Alauddin Makassar.

Khaerunnisa, dkk. (2016). Pengaruh Kepercayaan Agama, Logo Halal, Pemaparan, dan Alasan Kesehatan Terhadap Kesadaran Merek dan Keputusan Pembelian Makanan Halal Pada Penduduk Kota Malang”. Jurnal Ekonomi Bisnis, 21(1).

Madevi, F., \& dkk. (2017). Pengaruh Persepsi Label Halal Terhadap Citra Merek dan Minat Beli". Jurnal Ekonomi Dan Bisnis, 2(1).

Masy'adah, U. (2020). Pengaruh Islamic Branding, Personal Selling, dan Kualitas Produk Terhadap Keputusan Pembelian Produk Rabbani”. Fakultas Ekonomi dan Bisnis Islam, Institut Agama Islam Negeri Salatiga.

Nabeta, D. N., \& dkk. (2018). Konstruksi Konsumen Muslim Terhadap Labeling Halal (Studi Fenomenologi Penggunaan Kosmetik Halal di Kalangan Mahasiswa Politeknik Negeri Malang)". Jurnal Analisa Sosiologi, 1.

Nurlaila, S. (2020). Pengaruh Brand Awareness dan Label Halal Terhadap Keputusan Pembelian Produk Kosmetik Wardah Oleh Santriwati Komplek R Pondok Pesantren Al-Munawwir Krapyak Yogyakarta". Fakultas Dakwah dan Komunikasi, Universitas Islam Negeri Sunan Kalijaga Yogyakarta.

Putu, L. (2020). Pengaruh Celebrity Endorse, Service Quality, Dan Islamic Branding Terhadap Keputusan Pembelian Dengan Minat Beli Sebagai Variabel Intervening”. Febi, Ekonomi Syariah, Institut Agama Islam Negeri Salatiga.

Ramadhani, F. (2019). Pengaruh Labelisasi Halal, Harga, dan Celebrity Endorser Terhadap Keputusan Pembelian Produk Wardah". Febi, Universitas Islam Negeri Alauddin Makassar.

Risky, N. F. (2019). Pengaruh Aspek Islamic Branding, dan Pengetahuan Produk Terhadap Keputusan Pembelian Konsumen". Fakultas Ekonomi dan Ilmu Sosial, Universitas Islam Negeri Sultan Syarif Kasim Riau.

Sholihah, M., \& dkk. (2018). Pengaruh Brand Awareness, Norma Subyektif, Keyakinan Label Halal Terhadap Brand Attitude Untuk Meningkatkan Minat Beli Ulang Ice Cream Magnum". Jurnal Ekonomi, 2(2). 
Somantri, G. (2018). Aspek Islamic Branding Terhadap Keputusan Pembelian Produk Kosmetik Wardah". Fakultas Ekonomi dan Bisnis, Universitas Muhammadiyah Yogyakarta.

Sudaryono. (2019). Metodologi Penelitian Kuantitatif Kualitatif dan Mix Method. Edisi, 2.

Salaka, Ester Pradina, (2019), Pengaruh Word Of Mouth, Brand Image Dan Brand Awareness Terhadap Keputusan Pembelian Produk Kosmetik Wardah Kota Semarang. Undergraduate thesis, Faculty of Social and Political Science.

Schiffman, L. G., \& Kanuk, L. L. (2017). Consumer Behavior. Pearson Prentice Hall. Top Brand Award. (2020, June 28 ${ }^{\text {th }}$ ). www.topbrand-award.com.

Top 10 Populasi Umat Muslim Terbesar di Dunia. (2017, February 15 ). www.support.muslimpro.com.

Utami, S., \& Endang. (2018). Peran Brand Awareness Sebagai Mediasi Pengaruh Iklan Televisi dan Brand Ambassador Terhadap Repurchase Intention Produk Kecantikan Wardah".

Wiley. (2017). Metode Penelitian Untuk Bisnis. Edisi, 6 Buku 1.

Yulfan A. Nurohman, Pengaruh Komunikasi Sosial Media terhadap Persepsi Konsumen Pada Produk Kosmetik Halal, Vol. 10, No. 19, (Jurnal Among Makarti: 2017), h. 24.

Zainul, A., \& dkk. (2016). Pengaruh Kesadaran Merek, Asosiasi Merek, dan Kesan Kualitas Terhadap Keputusan Pembelian”. Jurnal Administrasi Bisnis, 41(1). 